Rev Med (São Paulo). 2012;91(ed. esp.):63-5.

\title{
Especialidades Médicas - Otorrinolaringologia
}

\author{
Ricardo Ferreira Bento
}

A Otorrinolaringologia é uma das mais antigas especialidades médicas. Atua em três dos cinco sentidos, audição, olfato e gustação além dos distúrbios da voz. A especialidade é essencial na comunicação humana pela audição e pela voz. Nas últimas décadas ampliou muito sua área de atuação abrangendo além das áreas básicas de ouvido, nariz e garganta, o estudo das apneias obstrutivas do sono, foniatria, glândulas salivares, cirurgia estética facial, medicina do trabalho, otoneurologia, cirurgia cérvico facial, audiologia, crânio maxilo facial e cirurgia da base anterior e posterior craniana.

A residência médica em Otorrinolaringologia é de três anos de duração e de acesso direto, porém com a expansão da especialidade quase todos os especialistas acabam realizando estágios de complementação especializada em sub-áreas específicas o que denota a necessidade de ampliar o numero de anos da residência como o que já ocorre há muitos anos nos Estados Unidos, na Europa, na Austrália, Japão e alguns países da América Latina.

A especialidade é tão abrangente que médicos clínicos gerais, pediatras, médicos que trabalham em pronto-socorro ou pronto atendimento tem que ter bom conhecimento da especialidade, pois chega a ser quase $40 \%$ do movimento de um pronto socorro geral e quase

\section{Satisfação pessoal que a especialidade pode dar}

A maior atração da especialidade é o fato da mesma ser clínico-cirúrgica, isto é na vida profissional o médico poderá atuar não só em cirurgia ou só em clínica e poderá mesclar as atividades ou até se dedicar somente à clinica, como alguns especialistas estão fazendo atualmente.

Outro aspecto é que a especialidade atende todas as faixas etárias, crianças, adultos e idosos.

Os sinais e sintomas que envolvem as doenças dessa área são muito incidentes, uma vez que tem principalmente na criança várias doenças infecciosas, como tonsilites, rinosinusites, otites. sentidos.

No idoso, surdez, tumores e diminuição dos

Do ponto de vista cirúrgico o médico pode se dedicar a microcirurgia ou grandes cirurgias. Tem uma alta incorporação de tecnologia, equipamentos diagnósticos e de cirurgia. Cirurgias de baixa, média e alta complexidade.

Outra grande satisfação que dá ao médico é o fato de apresentar alto índice de resultabilidade.

\section{Dificuldades da especialidade}

Além das dificuldades da medicina em geral a maior dificuldade é no início da carreira o investimento em materiais para se montar um consultório médico e equipamentos cirúrgicos.

No Brasil há também um numero reduzido de vagas para a residência médica o que torna uma das maiores relações candidato/vaga. 


\section{Mercado de trabalho}

O mercado de trabalho é muito grande, hoje temos cerca de 6000 especialistas no Brasil e há necessidade de mais especialistas e o mercado é bom com relação a outras especialidades.

\section{Rotina}

Salário (inicial, se estabiliza, se é pessoadependente).
O salário é na média das especialidades e não é pessoa dependente na área diagnóstica.

\section{Preconceitos e mitos em relação à especialidade}

Ainda existe um preconceito antigo que a otorrinolaringologia é uma especialidade menor que basicamente opera amigdalas! Não conhecendo a riqueza e amplitude da especialidade. 